\title{
Relational spaces and the geopolitics of community participation in two Tasmanian local governments: a case for agonistic pluralism?
}

\author{
Elaine Stratford, Denbeigh Armstrong and \\ Martina Jaskolski
}

The 'success' of sustainability is often premised on public participation and consensus among members of diverse communities. An analysis of two experiments in participatory governance in Tasmania underpinned by explicit commitments to sustainability and by tacit investments in deliberative democracy allows detailed reflection on claims about the efficacy of deliberative democracy, and encourages speculation about whether and to what extent an alternative model of agonistic pluralism may better accommodate conflicts in communities wrestling with resource use and distribution.

key words deliberative democracy agonistic pluralism implementation sustainability Tasmania qualitative research

\footnotetext{
Sustainable Communities Research Group, School of Geography and Environmental Studies, University of Tasmania, Hobart, TAS 7001, Australia

email: Elaine.Stratford@utas.edu.au
}

revised manuscript received 23 April 2003

\section{Sustainability, communicative rationality and agonistic pluralism}

According to the United Nations (1992), members of local communities - and not just local government authorities - should be working to achieve consensus on complex issues such as resource allocation, distribution and management, and systems of governance and planning. Relatedly, there are numerous examples from the northern hemisphere of local governments attempting to enhance opportunities for members of communities to participate in public life (Voisey et al. 1996; Coombes and Fodor 1997; Broderick 1999; Evans and Percy 1999). A consistently stated aim of such efforts has been to improve the practical implementation of sustainability rhetoric by developing community capacity and by emphasizing limited self-government, but these may be subject to vested interests and various forms of political favouritism (Stoker and Young
1993; Buckingham-Hatfield and Percy 1999; Hempel 1999). This situation is equally apparent in the antipodean margins among Tasmania's diverse 'communities of place and interest' (after Gibson and Cameron 2001), which is the subject of this paper.

Often subjected to the appellation 'weasel word', the term sustainability refers to the labour of enacting in local conditions and spaces at least six normative principles - integration, equity, precaution, continual improvement, the maintenance of diversity and public participation. Sustainability also assumes effective communication, generalized trust and facilitative leadership, and implies the possession among members of the public of highly developed civic and ecological literacy skills (Davies et al. 2002; see also Barry 1996; Bridger and Luloff 1999; Myers and Macnaghten 1998). Paramount among these skills is an appreciation that the common good - including concern for non-humans and non-citizens - needs 
to be considered alongside, and more often set above, private gain (Davidson 1999). This notion unsettles a narrow understanding of sustainability as exclusively about environmental management or sustainable development, and is just as noteworthy for what it tells us about politics, place and community (Hempel 1999), about relational spaces and geopolitics.

Questions about how to foster a praxis of sustainability have found at least partial responses in three interrelated ideas that comprise the philosophical framework of communicative rationality that underpins various iterations of deliberative democracy as constituted in Habermasian political philosophy (Habermas 19841990 1993). The first is that people's capacities for speech and action require them (on ethical grounds) to participate in rational debate. The second is that all participants in such processes have equal rights to introduce and question claims, or put forward reasoned, appropriate and moral arguments. The last is that no participant's rights should be diminished or suspended in the procedures of deliberation. Communicative rationality thus implies that consensus occurs around shared understandings of valid arguments and normative judgements, generated through open dialogue among informed equals capable of effective self-representation (the notion of ideal speech situations). Importantly, communicative rationality has been used by some political philosophers, notably John Dryzek (2000), to speculate about how to balance the common good (a central concern in sustainability discourses) and the rights of individuals; they envisage the striking of this balance between rationality and legitimacy as obligatory; and they distinguish between mere agreement and rational consensus, underscoring the importance of the latter in the pursuit of deliberative democracy (Mouffe 1999).

According to protagonists among political ecologists and planners, communicative rationality is inherent in citizen empowerment at the local level (Sagoff 1988; Gundersen 1995; Healey 1996) and is said to constitute deliberative democracy and sustainability. Yet this view is equivocal and, as McGuirk convincingly suggests, 'power and difference are impossible to set aside, and the idea that subjects can step outside the power grids that constitute them in order to reflect rationally, knowingly, and communicatively upon them' (2001, 213) is in dispute. In relation to the Tasmanian case and questions about deep-seated tensions over resource use and ways to advance a praxis of sustainability, this point is a crucial one and is explored later.

McGuirk's work is at least partially indebted to a series of arguments advanced by Chantal Mouffe (1995 19971999 2000, for example). For a number of years, Mouffe has asserted the need to refine a political theory alternative to variants of liberal democratic theories that privilege the aggregation of preferences, the reduction of citizenship to voting on these preferences, the protection of individual and private rights, and the stabilization of social relations via procedural government intended to foster cohesion and consensus. In these theories, 'relations of power and antagonisms are erased ... [which leaves] the typical liberal illusion of a pluralism without antagonism' (Mouffe 2000, 20). Mouffe's alternative argument is that a rationalist approach to politics ignores (is even blind to) the antagonism that 'constitutes an ever-present possibility in politics' (Mouffe 2000, 13). Such an approach also trivializes relations of subordination, the continual reconstitution of which weakens the possibility of a radical democratic politics (and, one asks, radical processes of sustainability?). Nevertheless, Mouffe is careful to question the salience of an extreme pluralism in which incommensurability is privileged to the point that nothing exists beyond a 'multiplicity of interest groups or of minorities' (Mouffe 2000, 20, 129). Rather, she reasserts Wittgenstein's idea that agreement about procedural matters requires agreement about substantive matters, too; 'procedures always involve substantial ethical commitments' (Mouffe 1999, no page), and argues that this runs contrary to much Habermasian thought.

Furthermore, because speech is never ideal, is always ontological, 'the very conditions of possibility of deliberation constitute at the same time the conditions of impossibility of the ideal speech situation' (Mouffe 1999, no page). The alternative that Mouffe offers she terms 'agonistic pluralism', in which the political refers to the antagonism that is constitutive of society and politics refers to practices, discourses and institutions that order and organize society but that are always open to the possibility of antagonisms because they are embedded in the political. Nevertheless, politics serves to domesticate hostility (Mouffe 1999 2000), to forge necessary, contingent and productive categories of us and them.

For Mouffe, agonistic pluralism presumes a space in which mechanisms have been found to 'establish the us/them discrimination in a way that 
is compatible with pluralist democracy' (Mouffe 1999, no page; emphasis added); a civil ethic of engagement supportive of the principles of democracy to which parties adhere, even while they remain adversarial - agonistic rather than merely antagonistic, understanding the need for substantive (though not irreconcilable) dissent and not mere procedural consensus underpinned by ongoing enmity. As Mouffe underscores,

When we accept that every consensus exists as a temporary result of a provisional hegemony, as a stabilization of power and that always entails some form of exclusion, we can begin to envisage the nature of a democratic public sphere in a different way ... To be sure pluralist democracy demands a certain amount of consensus, but such a consensus concerns only some ethico-political principles... [and] is bound to be a 'conflictual consensus'. This is why a pluralist democracy needs to make room for dissent and for the institutions through which it can be manifested... When the agonistic dynamic of the pluralist system is hindered because of a lack of democratic identities... there is a risk that this will multiply confrontations over essentialist identities and non-negotiable moral values. (1999, no page)

\section{Investing in deliberative democracy and communicative rationality - geopolitical conundrums in Tasmania}

Recent experiments in participatory governance in two municipalities in Australia's most peripheral and only island state of Tasmania raise questions for geographers and others about the validity of investments in deliberative democracy - about the constitution of relational spaces and a geopolitics of consensus and communicative rationality. In one of these local government areas, the Huon Valley, streetscape reference groups have been established in the four major townships in the period since 2000. Their brief has become the beautification of main streets to revitalize economic prospects, engender greater conviviality and trust, and reflect the natural and cultural heritage of the Valley's people. In the other municipal area of the City of Glenorchy, 12 precinct committees were constituted in 2000 with the collective task to progress the City's Community Plan, which was developed after a significant exercise in public consultation in the late 1990s about a vision for the municipality.

Both the Huon Valley streetscape reference groups and the Glenorchy City precinct committees are informed by orthodox understandings of sustainable development as a balance among economy, ecology and society now and for the future, in keeping with trends in so many places. In both local government areas, unemployment levels are higher than the national average, reliance on resource extractive activities and export industries is pronounced, and levels of trust in government are low (Tasmanian Department of Health and Human Services 2000; Australian Bureau of Statistics 2001; Stratford and Davidson 2001a). Using State and Federal legislation and policy, there are attempts in both local governments to facilitate rational public participation and balance diverse claims over resource management and planning (Davidson and Stratford 1999; Armstrong 2000; Jaskolski 2001; Stratford and Davidson 2001a).

By way of the streetscape reference groups and precinct committees, people in the townships of the Huon Valley and in the suburbs of the City of Glenorchy appear to be constituting new relational spaces and geopolitical associations that reflect what Nikolas Rose critically describes as 'the emergence of a new politics of conduct that seeks to reconstruct citizens as moral subjects of responsible communities' (2000, 1395). Yet threaded through these relational and geopolitical spaces of purported active citizenship and stewardship are others, more stridently constituted, that reflect long-standing tensions between (a) conservationists and developers, (b) right- and left-wing political groups and (c) those who would enlarge the brief of local government to embrace social and environmental planning and those who would constrain local governments' role to asset management. These tensions have been manifest in protests of anger in public meetings (especially, but not exclusively, about forestry), vandalism of property belonging to 'the opposition' and refusal among the parties to meet in facilitated discussions in attempts to reconcile differences.

The conflicts to which we refer have been rendered no less abrasive by the State's legislation and policy dating from 1993. At that time, a suite of legislation - the Resource Management and Planning System - was enacted, reflecting an overt rhetorical commitment to advance the principles of sustainable development, but one in which key industry sectors (forestry, mining exploration and marine farming) are exempt and are managed under other legislation providing only very limited participation). All 29 municipal authorities in the State have also been 
expected to have regard for sustainable development by observing the legislation on resource planning and development (Environmental Defenders Office 2000). Yet, most have struggled to meet the demands of the System (Committee for the Review of the State Planning System 1997). Extensive empirical work $^{1}$ also suggests that few personnel in Tasmanian local governments fully appreciate the importance of the assertion in the United Nations' Agenda 21 that as 'the level of governance closest to the people, they play a vital role in educating, mobilizing and responding to the public to promote sustainable development' (United Nations 1992, 28.1; see also Stratford and Davidson 2001b).

\section{Streetscape reference groups in the Huon Valley}

Any politics is also always a geopolitics, enacted in relational spaces among individuals and collectives whose identities, actions and associations or networks are at least partly inscribed by - while simultaneously etching - their context. Such is the case in the Huon Valley, Australia's southernmost municipality, where streetscape reference groups are of interest. The local government area is bordered on the west by the Tasmanian Wilderness World Heritage Area and on the east by the Huon River and D'Entrecasteaux Channel. It is one of the State's most important agricultural, forestry and fisheries areas (Armstrong 2000; Gee and Stratford 2001), over which the rural community is often deeply divided because of the ethical dilemmas associated with resource extraction and its implications for questions about how to live. Amongst farms and forest lands, the southern reaches are characterized by small townships, many dominated by holiday houses; the north is a transitional zone that has been attracting residents who commute to Hobart each day, drawn to the neck of the Valley because of its proximity to both the convenience of the capital city and the appeal of the rural landscape.

This relatively disadvantaged $\operatorname{area}^{2}$ is typified by distinct communities of place and interest whose members regularly clash over issues of resource use, conservation and extraction. Indeed, the Valley's history - from the dam protests of the 1970s and 1980s and including long years of restructuring in primary production - has been dominated by difficult interchanges among groups whose philosophical and practical approaches to land and place appear incommensurable. Some of those whose families have been in the district for several generations, and whose well-being fluctuates with the whims of international markets in primary goods, have priorities at odds with certain 'newcomers' and 'alternative lifestylers' who question entrenched methods and are perceived to threaten a long-standing way of life (but even these demarcations are crude representations of the geopolitical complexities that typify the lives of Valley residents, as conveyed to us in interviews spanning the period 1999-2003). Their relational spaces are constituted around polarized understandings of natural resource management, cultural heritage and sustainable development. Indeed, one Councillor doesn't 'think the community could be anymore divided or the Council itself we are poles apart at the moment... I honestly don't know how we can get it back together' (Anonymous 2002a).

Such conflicts and entrenched divisions task the Huon Valley Council. Nevertheless, the Council has reduced three planning schemes to one [draft] performance-based 'model framework' that may allow it to enact the principles of sustainable development as understood in the Resource Management and Planning System (Tasmanian Department of Primary Industries, Water and Environment 2000). It has also redeveloped its five-yearly Strategic Plan to integrate natural, human, social, physical, financial and organizational capital assets (Stratford and Davidson 2001a; Huon Valley Council 2002). In so doing, Council has moved away from a simple idea of sustainable development as a balance among economic, ecological and social activities to a more nuanced understanding of the need to integrate and accumulate capital assets, although its capacity to implement integrated management is yet to be tested.

Such innovations are interesting; but it is the streetscape reference groups - locally produced and negotiated - that are particularly intriguing as examples of participatory governance in action because they are not required at law, where strategic plans and planning schemes are. Their genesis is recent and is linked to the often uncompromising geopolitical and relational spaces that exist in the Valley, as we now elaborate.

Challenged by various - if partial - vagaries of international markets since the 1970s and by the successes of the conservation movement in the 1980s, the Huon Valley town of Geeveston has been in significant decline. Located on the west 
bank of the Huon River, Geeveston is a relational space of families and communities with longstanding social, cultural and politic-economic investments in forestry, in particular. Yet, by the late 1990s, two-thirds of the shops in the main street were empty, the bank, doctor's surgery and other professional offices had closed, and on its own the forestry interpretation centre in the town staffed by volunteers known as the 'Green Jackets' - was insufficient to produce significant change. There was, in fact, a palpable sense of despair about the community's future, recorded in both questionnaires and in-depth interviews with Geeveston residents (Stratford and Davidson 1999; Armstrong 2000).

Given this context, it is significant that the first streetscape reference group in the Huon Valley formed in Geeveston in 2000 (rather than in one of the other towns of the Valley). First championed by the then Manager of Community Development Services and a local elected representative, the group (which included a number of Green Jackets) 'evolved rather than being planned and provided a positive opportunity to participate, communicate and achieve' (Doyle personal communication 2002), building the previously undermined self-esteem and confidence of participating community members.

In 2001, the work of the Geeveston streetscape reference group came to prominence in Tasmania when the Huon Valley Council received a State Government grant of AUS $\$ 250000$ (US\$150 604, $£ 95$ 330, Euro $\$ 138258$ at 31 March 2003) to revitalize the town's main street, enabling it to be marketed as gateway to the highly political, jointly funded Tahune [Forest] Airwalk (AUS\$4.5 million, US\$2.71 million, $£ 1.71$ million, Euro $\$ 2.48$ million at 31 March 2003). Now a premier tourist attraction, the Airwalk resulted from a partnership among the State Government, Forestry Tasmania and the Huon Valley Council (Tasmanian Government Media Office 2001; Forestry Tasmania 2002). Its construction high in the canopy of a wet temperate rainforest at the confluence of two major river systems served to highlight deep and entrenched divisions in the Valley and State communities over the conservation or development of the southern forests (which include significant areas of old growth rainforest). It also significantly boosted the economic well-being of the Geeveston community, with new businesses now taking up the vacancies in the main street, and with a new 'community bank' (the Bendigo Bank) in place. Thus, the reference group's activities exist in a context of ongoing tensions about resource use and management, and the 'main street' is a space that will ultimately symbolize the level to which diverse geopolitical and relational spaces (for youth, adults, forest heritage, conservation messages and the like) will be accommodated.

Since 2000, three other streetscape reference groups have formed in the regional capital of Huonville and the two other regional centres of Dover and Cygnet. Any members of a community may become members of the relevant reference group, and will stay so until they ask to be taken from the lists. They receive agenda, minutes and updates, and can be involved to whatever level they see fit. All members are also categorized as volunteers by Council and are covered by its insurance.

The streetscape reference groups constitute examples of grassroots public participation in local governance and - although not labelled as such by those involved - as local sustainability initiatives. Numerous benefits flow from them, not least of which is that people 'have become doers, and have achieved marvellous things in a short time' (Doyle personal communication 2002). While the groups' activities have been restricted to townscape refurbishment - design, choosing pavers, bins, seats, plantings, placements and the like - their interaction with Council engineers, planners and outside workforce has 'resulted in both Council and community growing to understand the others' perspectives', although this differs from group to group. Nonetheless, a 'cultural shift has occurred with more staff now thinking through the benefits of participation' (Doyle personal communication 2002). As a result of these interactions, complaints against Council (measured as part of local governments' performance management commitments to the State) have diminished. It has also been suggested that (a) participants have a better understanding of Council's diverse roles and the calls upon its staff and resources; (b) they have developed trust, confidence and various skills and capacities from landscaping to the administration of meetings; and (c) Councillors are seeing the manifold advantages of participation by community members in what has traditionally been core business of infrastructure provision and maintenance.

The streetscape reference groups are also noteworthy because desire and capacity to participate and trust in leaders had been diminished in the 
Huon Valley, as elsewhere in the State (Tasmanian Department of Health and Human Services 2000). Despite these long-standing impediments to participation in local governance, elected representatives have given qualified support to the streetscape reference groups as participatory structures that may give people in the Valley hope for the future. Invoking the idea of moral citizens as critical to this task, one Councillor suggested that:

We need to lessen the gap between those who decide and those who are impacted on by those decisions. I believe that individual responsibility and authority is a basic 'requirement', an essential ingredient for a healthy society - I think we're in a transitional stage, moving from dependency on institutions (local/state/ federal government) during the 1950s-1990s, to recognising the societal need for personal authority/potential to help the well-being and successful functioning of a community.... (Anonymous 2001b)

Less optimistically, perhaps, another Councillor underscores the impediments to structures of representative democracy and rational and allegedly deliberative forms of governance:

[One of the challenges facing us in the next 12 months is] whether Council can function democratically and effectively as an instrument of the community it represents - i.e. whether policy is created by the community through elected councillors or by State government and industrial influence through the Council bureaucracy. Divisiveness results from top down...p proposals and encouragement of political polarisations. (Anonymous 2001c)

Given this opinion that Council supports community leadership but is constrained by the State and the bureaucracy, it is surprising that - beyond the completion of townscape projects - the groups' future is unclear, despite their clear commitment to issues beyond the purview of main street refurbishment. This lack of clarity arises because their constitution as 'creatures of community' was unsettled in early 2002. At that time, terms of reference were introduced by Council to formalize the groups' conduct and scope because some elected representatives were concerned that groups were being given substantial annual allocations and should be made accountable - in principle, an understandable requirement. The Local Government Act 1993 makes Councillors responsible for the sound management and distribution of municipal resources, but the 'domestication' of the streetscape reference groups has not been universally welcomed (Young personal communication 2002), and anecdotal evidence suggests that the groups had been accountable in any case.

Dissatisfaction with the imposition of terms of reference may also be better understood if one appreciates the Valley's political history, which has been shaped by a powerful few in government, primary industry and manufacturing, whose authoritarianism and conduct have engendered high levels of dependency and a relative unwillingness among traditional residents to question the status quo (Davidson forthcoming; Young 1995/6). Despite this legacy, the evidence suggests that elected representatives see the need for more community involvement in local governance. ${ }^{3}$ However, ideas about the devolution of power to local coalitions are less comfortable for them and in Geeveston some group members seek no further responsibility outside defined terms of reference. In that respect, while the groups serve important functions, they are not structures through which long-term or widespread participatory governance for sustainability is likely to be fostered - and nor were they designed for such purposes.

Notwithstanding this observation, the existence of the Geeveston group has raised expectations among other members that local governance for local sustainability is more than a Council matter, and these different ideas about the potential and direction of the group have caused a degree of internal conflict. One of the ways in which this tension is manifest relates to questions about whether, how and to what extent to involve young people in the group's deliberations and activities. It has become apparent that some young people are resisting the transformation of the streetscape and the presence of tourists in the town. Some group members view this resistance as a means by which to justify the policing of young people; others seek to enfranchise the young people such that they are able to participate in the group's activities in ways that are not merely token. As a result, long-standing practices of retreating into antagonistic postures to maintain the status quo may erode the capacity to engage more agonistically. Indeed, those wishing to advance local governance have come to understand the limited efficacy of trying to influence such entrenched attitudes and responses to change.

\section{Precinct committees in the City of Glenorchy}

Glenorchy is one of five municipalities in the capital city of Hobart, its suburbs scattered on 
rolling foothills on the north-eastern flanks of Mount Wellington, and on riverine plains bordering the western shores of the Derwent River. As well as its natural attributes and areas, the municipality has many land uses, including heavy and light industry, commerce, agriculture and horticulture, transport, housing and recreation. Like the Huon Valley, it is characterized by relative disadvantage ${ }^{4}$ - a reputation that Council began to address in the early 1990s, in part by involvement in the then Australian Labor Government's 'Better Cities Program' (Wills no date).

From the late 1990s, Council adopted a Community Participation Program partially modelled on Oregon Shines (Mackey personal communication 2000; see also Oregon Progress Board 2001). This process became public in 1998 and reflects the principles of the RMPS and the Tasmanian Local Government Act 1993 that emphasize the advancement of sustainability, public participation and local governance, especially in the preparation of local government strategic plans and planning schemes.

The Community Participation Program was championed by the elected and appointed leaders of Council, in particular the Mayor and the then General Manager, and was based on the generation of a Community Plan from a process of externally facilitated community consultations to gauge the visions and goals that Glenorchy's citizens held for the municipality. There were initial meetings in June 1999 in 12 precincts identified for that consultative purpose. Community members were asked to identify problems in their areas, describe their vision to address these problems, and outline strategies and priorities for implementing this vision (Wills no date). Other meetings were held in September 1999 for different communities of interest. Over 50 meetings were attended by more than 400 residents and the Plan was officially adopted by Council in April 2000 (Mackey personal communication 2001). In it, the citizens of Glenorchy acknowledged the importance of a healthy environment, community leadership, participation, diversity and economic opportunity (Glenorchy City Council 2000). Binding partnerships were also established with several community groups and organizations, and with the State Government of Tasmania to advance these agenda (Tasmanian Government and Glenorchy City Council 2000).

The implementation of the Plan is a long-term project for Council in partnership with 12 precinct committees that were created as special committees of Council under the Local Government Act 1993 after the consultation phase finished. The task of the precinct committees is to foster ongoing involvement and participation in local governance among residents. The 'benefits for Council lie in the sharing of decision-making, the ability to better ascertain citizen priorities and wishes, the greater targeting of services and better distribution of resources' (Mackey no date, 7).

From among community members in attendance, each precinct committee selects a convenor, a secretary and a treasurer to run meetings and undertake executive duties. They serve for 12 months and may be re-elected. However, its statutory obligations require Council to restrict the power of committees to advancing recommendations for action and provide advice on community matters, and the monthly public meetings are attended by an Alderman (not resident in the precinct) and a Council liaison officer to aid this process.

Our research, work by Martin (2003) and limited information available from consultants hired by Council to review the system in 2002/3 all suggest that the precinct system appears to have affected the conduct of local governance and the pursuit of local sustainability in the City of Glenorchy. It provides ongoing mechanisms for community participation, and fosters civicness, community involvement, social capital and local action, all of which are 'inside' sustainability. Some committee members report that being involved in the precincts has increased their involvement with special task forces (on waste or water management, for example) formed by or at the request of precinct committees. Some note that they are now participating in other community organizations and feel more confident than they had before being involved in the precinct system. Some welcome the existence of the precinct committees as new community fora that enhance opportunities to participate in local decisions. Others say they feel more included in and informed about local politics and planning, and therefore better prepared to contribute in local decision-making - to exercise leadership and work through conflicts and concerns.

Nonetheless, the precinct system is constrained by various factors, such as a lack of involvement among young people (although their particular needs have been addressed in various ways, including through a Youth Task Force, since the mid-1990s). Levels of participation in precinct committees among the adult population aged under 
50 are also limited. Council does inform community about Council business via a community newspaper, regular surveys, specialist committees of Council and community services, but it was hoped by the architects of the system that the precinct committees would be a powerful source of local democratic involvement in community issues for sustainable development. That does not yet appear to have happened. Both precinct committee members and Council staff have also mentioned that interactions and discussions at meetings can be difficult because of abrasive or incompatible personalities. Furthermore, the views and decisions of precinct committee members sometimes conflict with the technical knowledge and advice of officers or the opinions of elected representatives.

The Council faces two other challenges in fostering participation and deliberation among citizens and these again highlight the potential salience of agonistic pluralism as an alternative to mere procedural consensus underpinned by antagonism and rancour. First are major ideological divisions in Council in which the Mayor's leadership was publicly and forcefully questioned during 2000 and 2001 by three Aldermen who maintain that Councils are corporations, and view precinct committees as a waste of ratepayers money, a claim which narrowly circumscribes the meaning of community and the role of citizens and Council. At local government elections in October 2002, this conservative faction was increased in size from three to five, and these Aldermen have now refused to have anything to do with the precinct committees; the effects of this manoeuvre are yet to be determined, but in principle serve to undermine the efficacy of the system.

Second, while the Plan is premised on a commitment to sustainable development per se, it remains the case that the pursuit of sustainability is very limited among precinct committees. We think this 'failure' to build committee members' capacities stems from an apparent reluctance to systematically work through significant and difficult issues related to environmental ethics and the management of resources (see also Martin 2003): to do so would generate discussion about matters that are - without an ethic of engagement that is agonistic traditionally deeply divisive in Tasmanian communities: access of youth to public spaces; the management of natural and cultural heritage; land use and development; transport; and waste and water management among them.

\section{From case to theory}

How might these two experiments in elements of participatory governance in the Huon Valley and Glenorchy be theorized? In particular, is it possible to speculate about the extent to which approaches to participatory governance might be more productively framed for sustainability praxis? Are there useful applications to be drawn from Mouffe's ideas about agonistic pluralism rather than from other ideas about deliberative democracy and the privilege given to particular expressions of consensus, especially accounting for the ongoing conflict that typifies interactions among various communities of interest in these places? Certainly, our analyses suggest that the pursuit of sustainability currently assumes the constitution and/or transformation of relational spaces such that agreement will be fostered among informed equals. But as Mouffe observes,

\begin{abstract}
Consensus in a liberal-democratic society is - and will always be - the expression of a hegemony and the crystallization of power relations. The frontier that it establishes between what is and what is not legitimate is a political one, and for that reason it should remain contestable. To deny the existence of such a moment of closure, or to present the frontier as dictated by rationality or morality, is to naturalize what should be perceived as a contingent and temporary hegemonic articulation of 'the people' through a particular regime of inclusion-exclusion. The result of such an operation is to reify the identity of the people by reducing it to one of its many possible forms of identification. (2000, 48-9)
\end{abstract}

Relatedly, it is our contention that the devolution of responsibility for governance and the constitution of sustainability in practice in local communities is conceived erroneously as a rational process whereby those in 'possession' of leadership build the procedural capacities of community members to meet the tasks of transforming social and institutional practices such that sustainability principles are advanced (Barber 1984; Dryzek 2000). These ideas about participatory governance return us to the differences between deliberative democracy and agonistic pluralism (Burgess et al. 1998; Irwin 1995; McGuirk 2001; Rydin and Pemington 2000).

The transfer of power from government to the people' in morally mature communities is seen by the advocates of deliberative democracy to depend on communicative rationality, engaging what Rose (2000) terms a new politics of behaviour, or ethopolitics. At best, this transference is emergent 
in the Huon Valley and Glenorchy, and communicative rationality is limited because it does not satisfactorily account for the existence in these places of webs of '[p]ower and resistance [that] are together the governance machine of society ... in the sense that together they contribute to the truism that "things never quite work" ' (Hunt and Wickham 1994, 83; see also Foucault 1972 1991). The relative failure of communicative rationality in these relational and geopolitical spaces - in which conflicts over sustainability issues are deeply rooted - also exists because Councillors, Council staff and community members remain torn about the meaning of the term sustainability and the processes involved in its pursuit, and seem reluctant to accept its relative and relational attributes, its contingency.

However, these dilemmas may be addressed if consensus is not manifestly privileged as essential to sustainability processes, and thus to the operation of participatory democratic structures such as those which have emerged in Tasmania. In this respect, echoing Mouffe's arguments, McGuirk (2001) suggests a shift in focus to the productive attributes of conflict and democratic compromise. Neither author articulates the details of such a shift beyond the radical politicization of planning such that

the outcomes of planning decisions [for example, those made by streetscape reference groups or precinct committees and ratified by councils] do not result in the systematic exclusion of particular social identities or value systems [such as those held by young people, greens, or non-ratepaying residents]. (McGuirk 2001, 214)

Clearly, the idea of these relational spaces of dissent sits uncomfortably in Tasmanian local government circles at the present time.

McGuirk's suggestion is important given that local sustainability initiatives are especially affected by tensions between, on the one hand, the participation, democratic ethic and facilitative (rather than authoritarian) leadership that sustainability demands and, on the other, traditional and entrenched methods of local government in which these things are under-valued. This tension is highly problematic if one accepts the proposition that, in order to be in a position to make informed decisions that foster sustainability, members of communities require high levels of ecological literacy (Lyons et al. 2001), a sound understanding of sustainability and the capacity to engage civically in robust debates without descending into the destructive tendencies of the political, the antagonistic. Indeed, as Mouffe argues, 'Democratic individuals [and, we add, relational spaces] can only be made possible by multiplying the institutions, the discourses, the forms of life that foster identification with democratic values' $(2000,96)$. These capacities remain constrained in the Huon Valley and Glenorchy City councils, in part because the relational spaces are internally fractured along lines most starkly typified by conflicts over conservation and development. Furthermore, the cases presented here suggest that discussions about how to engender a new ethic of engagement that would render the conflicts of sustainability and democracy productive rather than antagonistic are unlikely to occur in the Huon Valley and City of Glenorchy in the near future.

\section{By way of conclusion}

In this paper we have argued that, contrary to the arguments of some political ecologists and planners, communicative rationality is not inherent in citizen empowerment at the local level. We have challenged the efficacy of deliberative democracy and speculated about the possibilities of agonistic pluralism as an alternative model that better accommodates the conflict and power inherent in community debates over the distribution and management of resources. The deliberative democratic pursuit of consensus via communicative rationality is unrealistic and ultimately may be socially unjust. We argue that the ideal speech situation is unachievable and that power differentials inherent and persistent in society will always be present within the geopolitical and relational spaces of participatory governance. The problem with consensus, to underscore Mouffe's comment quoted earlier, is that it is always 'the expression of a hegemony and the crystallization of power relations' (Mouffe 2000, 48-9), and that the outcome of debate will be contingent upon particular regimes of inclusion and exclusion. Agonistic pluralism makes explicit the power differentials in society and acknowledges the productive potential of conflict and democratic compromise. In this way, the maintenance of diversity, at risk of elision in deliberative democratic processes, is ensured through the creation of spaces for dissent.

Yet, while agonistic pluralism may better accommodate conflict through making explicit relations 
of power, it does not yet resolve the problem of power in practical terms that are accessible to members of local communities. Evident in both the Huon Valley and Glenorchy municipalities are powerful agents - in particular those with vested interests - who deploy strategies of antagonism in order to maintain the status quo. The intriguing (and doubtless vexing) question remains of how to improve the capacity of agents to negotiate the dominance of vested interests without debate slipping back into antagonism. In short, an applied ethic of engagement flowing from the framework of agonistic pluralism is warranted, and much remains to be done to achieve such ends.

\section{Notes}

1 Stratford E and Davidson J, Advancing Sustainable Development in Tasmania Parts I and II: Establishing the Role of Sustainability Advocates in Local Communities, Australian Research Council Small and Institutional Research Grants funding, 2000 and 2001. Drawn from 70 in-depth interviews with local government officers.

2 In 2000, there were 13625 residents in the Huon Valley (Australian Bureau of Statistics 2001), and the median age was 34 . Almost 42 per cent of the 3593 families had young dependants and 7 per cent had adult children. Just over 13 per cent of families were headed by single parents. Professionals and associate professionals totalled 20 per cent of the 4647 aged over 15 in the labour force, compared to 13 per cent in clerical, sales and service occupations, and 12 per cent in trades and related occupations. A further 55 per cent of people in the labour force were occupied mainly in forestry, agriculture and fisheries. The median personal weekly income was AUS\$224 (US\$123, $£ 81$ or Euro $\$ 127$ in August 2002) compared to an Australian average of AUS\$292 per week (US\$161, $£ 106$ or Euro\$165) (http://www.xe.com, Accessed January 2002). In 1996, 13 per cent of the labour force was unemployed, whereas the unemployment rate Australia-wide was 9 per cent (Australian Bureau of Statistics 1996 2001).

3 Five per cent of Huon Valley householders surveyed in 1999 were, for example, asked a range of questions about local governance. Of these 231 respondents, 38 per cent stated that Council did not encourage public participation and 30 per cent were uncertain. Despite this, 50 per cent agreed or strongly agreed that Councillors were accessible to community members. In effect, these findings suggest that respondents saw Councillors as formal leaders but did not see the institution of Council as inclusive.

4 In 2000, there were nearly 44000 residents (Australian Bureau of Statistics 2001). Almost 35 per cent of the nearly 12000 families in the municipality had dependent children, and over 18 per cent of families were headed by single parents, and many working age people were involved in a range of professional, clerical, trades and labouring positions. However, the median personal weekly income was AUS\$253 (US\$139, £92 or Euro\$143 in August 2002) compared to the Australian average of AUS\$292 (US\$161, £106 or Euro\$165) per week, and 11 per cent of the labour force was unemployed, compared with 9 per cent Australia-wide. Relative to other municipalities in Greater Hobart, Glenorchy had significant numbers of people on unemployment, youth allowance, aged, mature age, disability, single parent or carer benefits and payments, although some other municipalities had higher rates per thousand population on such benefits (Australian Bureau of Statistics 1996 2001).

\section{References}

Australian Bureau of Statistics 1996 Census of population and housing basic community profiles (http:// www.abs.gov.au/ausstats) Accessed January 2002

Australian Bureau of Statistics 2001 Regional statistics Tasmania ABS, Canberra

Anonymous 2002a Huon Valley Councillor personal communication February

Anonymous 2002b Huon Valley Councillor A personal communication August

Anonymous 2002c Huon Valley Councillor B personal communication August

Armstrong D 2000 Narratives of community and sustainability: the case of Cygnet and Geeveston in Tasmania's Huon Valley Unpublished Honours Thesis School of Geography and Environmental Studies, University of Tasmania, Hobart

Barber B 1984 Strong democracy: participatory politics for a new age University of California Press, Berkeley

Barry J 1996 Sustainability, political judgement and citizenship: connecting green politics and democracy in Doherty B and de Geus $\mathbf{M}$ eds Democracy and green political thought: sustainability, rights and citizenship Routledge, London 115-31

Bridger J C and Luloff A E 1999 Toward an interactive approach to sustainable community development Journal of Rural Studies 15 377-87

Broderick S 1999 The state versus civil society: democracy and sustainability in Ireland Democracy and Nature $5343-56$

Buckingham-Hatfield S and Percy S 1999 Keys to a sustainable environment: education, community development and local democracy in Buckingham-Hatfield S and Percy S eds Constructing local environmental agendas: people, places and participation Routledge, London 1-17

Burgess J, Harrison C M and Filius P 1998 Environmental communication and the cultural politics of environmental citizenship Environment and Planning A 30 1445-60 
Committee for the Review of the State Planning System 1997 Planning system review 1997 Government Printer, Hobart

Coombes T and Fodor M 1997 Community involvement in Local Agenda 21: the experience of Bristol City Council in Farthing S M ed Evaluating local environmental policy Avebury Press, Aldershot 97-109

Davidson J 1999 Sustainable development, business as usual or a new way of living? Environmental Ethics Spring 25-42

Davidson $\mathbf{J}$ forthcoming Citizenship and sustainability in dependent communities: the case of the Huon Valley region in southern Tasmania Local Environment

Davidson J and Stratford E 1999 Sustainability and community in Tasmania's Huon Valley Occasional Paper 1 Sustainable Communities Research Group, University of Tasmania, Hobart

Davies B, Stratford E and Davidson J 2002 National policy on consultation and participation for the Planning Institute of Australia The SD Group and Inspiring Places, Hobart

Doyle G 2002 Huon Valley Council staff personal communication May

Dryzek J S 2000 Deliberative democracy and beyond Oxford University Press, Oxford

Environmental Defenders Office 2000 Environmental law handbook EDO, Hobart

Evans R and Percy S 1999 The opportunities and challenges for local environmental policy and action in the UK in Buckingham-Hatfield S and Percy S eds Constructing local environmental agendas: people, places and participation Routledge, London 172-85

Forestry Tasmania 2002 Forestry Tasmania current topics. Tahune AirWalk (http://www.forestrytas.com.au/ forestrytas/pages/tahune_air_walk.htm) Accessed May 2002

Foucault M 1972 The archaeology of knowledge 1st American edition Pantheon Books, New York

Foucault M 1991 Governmentality in Burchell G, Gordon $\mathbf{C}$ and Miller P eds The Foucault effect: studies in governmentality Harvester Wheatsheaf, London 87-104

Gee D and Stratford E 2001 Public participation and integrated planning in the Tasmanian Private Timber Reserve process Environment and Planning Law Journal $1854-70$

Gibson K and Cameron J 2001 Transforming communities: towards a research agenda Urban Policy and Research 19 7-24

Glenorchy City Council 2000 Community plan GCC, Hobart

Gundersen A 1995 The environmental promise of democratic deliberation University of Wisconsin Press, Madison

Habermas J 1984 The theory of communicative action volume 1. Reason and the rationalisation of society Polity Press, Cambridge

Habermas J 1990 Moral consciousness and communicative action Lenhardt $\mathrm{C}$ and Weber Nicholson S trans Polity Press, Oxford
Habermas J 1993 Justification and application Lawrence F trans Polity Press, Oxford

Healey P 1996 The communicative turn in planning theory and its implication for spatial strategy formation Environment and Planning B Planning and Design 23 217-34

Hempel L C 1999 Conceptual challenges in building sustainable communities in Mazmanian D A and Kraft M E eds Towards sustainable communities: transition and transformations in environmental policy MIT Press, Cambridge MA $43-74$

Hunt A and Wickham G 1994 Foucault and law: towards a sociology of law as governance Pluto, London

Huon Valley Council 2002 Strategic plan Huon Valley Council, Huonville

Irwin A 1995 Citizen science, a study of people, expertise and sustainable development Routledge, London

Jaskolski M 2001 Local governance and sustainability: a Tasmanian case study Unpublished Honours Thesis School of Geography and Environmental Studies, University of Tasmania, Hobart

Lyons M, Smuts C and Stephens A 2001 Participation, empowerment and sustainability. (How) do the links work? Urban Studies 38 1233-51

Mackey L 2000 Glenorchy City Council Manager Community Development personal communication July

Mackey L 2001 Glenorchy City Council Manager Community Development personal communication January

Mackey L no date Citizen participation and neighbourhood empowerment GCC, Hobart

Martin C 2003 Local sustainability and community: issues of social capital, governance and capacity Unpublished Masters of Environmental Management Thesis University of Tasmania, Hobart

McGuirk P M 2001 Situating communicative planning theory, context, power, and knowledge Environment and Planning A 33 195-217

Mouffee C 1995 Post-Marxism: democracy and identity Environment and Planning D 13 259-65

Mouffe C 1997 Carl Schmitt and the paradox of liberal democracy Canadian Journal of Law and Jurisprudence 10 (21) no pages (wysiwig://main.175/http://www.lexis.com)

Mouffe C 1999 Deliberative democracy or agonistic pluralism? Social Research Fall no pages

Mouffe C 2000 The democratic paradox Verso, London

Myers G and Macnaghten P 1998 Rhetorics of environmental sustainability: commonplaces and places Environment and Planning A 30 333-53

Oregon Progress Board 2001 Oregon shines (http:// www.econ.state.or.us/opb/) Accessed December 2001

Rose N 2000 Community, citizenship and the third way American Behavioral Scientist 43 1395-411

Rydin Y and Pemington M 2000 Public participation and environmental planning: the collective action problem and the potential of social capital Local Environment 5 153-70

Sagoff M 1988 The economy of the earth Cambridge University Press, Cambridge 
Stoker G and Young S 1993 Sustainable development at the level of the city in Stoker G and Young S eds Cities in the 1990s Longman, Essex 64-96

Stratford E and Davidson J 1999 Issues of sustainability and community in Tasmania's Huon Valley Occasional Paper No 1 Sustainable Communities Research Group, University of Tasmania, Hobart

Stratford E and Davidson J 2001a Strategic issues, trends and options for the Huon Valley Municipality The SD Group, Hobart

Stratford E and Davidson J 2001b Leaders in sustainability workshops for Tasmanian local governments UNITAS Consulting, Hobart

Tasmanian Department of Health and Human Services 2000 First results of the 1998 healthy communities survey DHHS, Hobart

Tasmanian Department of Primary Industries, Water and Environment 2000 Tasmanian model framework for planning schemes DPIWE Hobart (http://www.dpiwe.tas.gov.au/ env/mfps.pdf) Accessed January 2002

Tasmanian Government and Glenorchy City Council 2000 Partnership Agreement

Tasmanian Government Media Office 2001 Geeveston street upgrade starts today Monday 8 October

United Nations 1992 Agenda 21 (http://www.un.org/ esa/sustdev/agenda21.htm) Accessed November 2001

Voisey H, Beuermann C, Sverdrup L A and O'Riordan T 1996 The political significance of local agenda 21: the early stages of some European experience Local Environment 1 $33-50$

Wills J no date Draft: community planning in Glenorchy School of Management and Policy University of Canberra, Canberra

Young J 1995/6 Back to the future: choosing a meaning from regional history Tasmanian Historical Studies 5 114-31

Young J 2002 Franklin resident personal communication May 